\title{
Epithelial Neutrophil Activating Peptide-78: A Novel Chemotactic Cytokine for Neutrophils in Arthritis
}

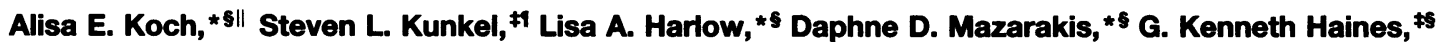 \\ Marie D. Burdick, ${ }^{\neq 1}$ Richard M. Pope, ${ }^{\star \$ \|}$ Alfred Walz, ${ }^{* \star}$ and Robert M. Strieter ${ }^{\star 1}$ \\ Departments of $*$ Medicine and ${ }^{\ddagger}$ Pathology, ${ }^{8}$ Northwestern University Medical School, and "Veteran's Administration Lakeside Medical \\ Center, Chicago, Illinois 60611; 'The University of Michigan Medical Center, Ann Arbor, Michigan 48109; and **Theodor Kocher \\ Institute, University of Bern, Bern, Switzerland
}

\begin{abstract}
We and others have shown that cells obtained from inflamed joints of rheumatoid arthritis (RA) patients produce interleukin-8, a potent chemotactic cytokine for neutrophils (PMNs). However, IL-8 accounted for only $40 \%$ of the chemotactic activity for PMNs found in these synovial fluids. Currently, we have examined the production of the novel PMN chemotactic cytokine, epithelial neutrophil activating peptide-78 (ENA-78), using peripheral blood, synovial fluid, and synovial tissue from 70 arthritic patients. RA ENA-78 levels were greater in RA synovial fluid $(239 \pm 63 \mathrm{ng} / \mathrm{ml})$ compared with synovial fluid from other forms of arthritis $(130 \pm 118 \mathrm{ng} / \mathrm{ml})$ or osteoarthritis $(2.6 \pm 1.8 \mathrm{ng} / \mathrm{ml})(P$ $<0.05)$. RA peripheral blood ENA-78 levels $(70 \pm 26 \mathrm{ng} /$ $\mathrm{ml})$ were greater than normal peripheral blood levels $(0.12 \pm 0.04 \mathrm{ng} / \mathrm{ml})(P<0.05)$. Anti-ENA-78 antibodies neutralized $42 \pm 9 \%$ (mean $\pm S E$ ) of the chemotactic activity for PMNs found in RA synovial fluids. Isolated RA synovial tissue fibroblasts in vitro constitutively produced significant levels of ENA-78, and this production was further augmented when stimulated with tumor necrosis factor-a (TNF- $\alpha$ ). In addition RA and osteoarthritis synovial tissue fibroblasts as well as RA synovial tissue macrophages were found to constitutively produce ENA-78. RA synovial fluid mononuclear cells spontaneously produced ENA-78, which was augmented in the presence of lipopolysaccharide. Immunohistochemical localization of ENA-78 from the synovial tissue of patients with arthritis or normal subjects showed that the predominant cellular source of this chemokine was synovial lining cells, followed by macrophages, endothelial cells, and fibroblasts. Synovial tissue macrophages and fibroblasts were more ENA-78 immunopositive in $\mathbf{R A}$ than in normal synovial tissue $(P<0.05)$. These results, which are the first demonstration of ENA-78 in a human disease state, suggest that ENA-78 may play an important role in the recruitment of PMNs in the milieu of the inflamed joint of RA patients. (J. Clin. Invest. 1994. 94:1012-1018.) Key words: chemotaxis $\bullet$ rheumatoid arthritis • macrophage $\cdot$ leukocyte $\cdot$ fibroblast
\end{abstract}

Address correspondence to Alisa E. Koch, M.D., Northwestern University Medical School, Department of Medicine, 303 E. Chicago Avenue, Ward Building 3-315, Chicago, IL 60611.

Received for publication 16 December 1993 and in revised form 19 May 1994.

The Journal of Clinical Investigation, Inc.

Volume 94, September 1994, 1012-1018

\section{Introduction}

The rheumatoid arthritis (RA) synovial tissue is replete with macrophages, lymphocytes, and chronic inflammatory cells surrounding the formation of new blood vessels (1). In contrast to the subpopulation of cells found in the RA synovial tissue, synovial fluid contains predominantly neutrophils (PMNs) (1). Although PMN chemotactic factors such as interleukin-8 (IL8 ), C5a, and leukotreine $B_{4}$ have previously been found to mediate PMN influx into the synovial fluid of RA patients, these factors may not fully account for all of the PMN chemotactic activity found in these synovial fluids (1).

Recently, we have identified a novel chemotactic cytokine, epithelial neutrophil activating peptide-78 (ENA-78), ${ }^{1}$ a $78-$ amino acid protein member of the IL-8 or C-X-C chemokine supergene family (2-4). This chemokine is a potent chemotactic and less potent chemokinetic factor for PMNs and may play a role in the recruitment of inflammatory leukocytes into the joints of RA patients. The role of this chemokine in RA has not been determined.

In this study, we have found significantly greater concentrations of ENA-78 in RA synovial fluids than from either osteoarthritis (OA) or other inflammatory and noninflammatory forms of arthritis. In addition, peripheral blood from RA patients demonstrated significantly greater elevations of ENA-78 than peripheral blood isolated from normal subjects. Isolated fibroblasts in vitro from the synovial tissue of RA patients produced both constitutive and inducible levels of ENA-78 in the presence of tumor necrosis factor- $\alpha$ (TNF- $\alpha$ ). RA synovial tissue and synovial fluid-derived mononuclear cells in culture were found to produce ENA-78, especially in the presence of lipopolysaccharide (LPS). The expression of ENA-78 protein was predominantly localized to the lining layer, macrophages, endothelial cells, and fibroblasts from both RA, OA, and normal synovial tissues. However, more macrophages and fibroblasts from RA synovial tissues were ENA-78 positive than normal synovial tissue. These studies support the notion that ENA-78 plays an important role in the elicitation of PMNs into the joints of RA patients.

\section{Methods}

Reagent preparation. Human recombinant $\mathrm{IL}-1 \beta$ with a specific activity of $5 \times 10^{8} \mathrm{U} / \mathrm{mg}$ was purchased from R \& D Systems, Inc. (Minneapolis, MN). Human recombinant TNF- $\alpha$ with a specific activity of 1.3 $\times 10^{7} \mathrm{U} / \mathrm{mg}$ was a gift from Upjohn Co. (Kalamazoo, MI). LPS (Esch-

1. Abbreviations used in this paper: ENA-78, epithelial neutrophil activating peptide-78; MCP-1, monocyte chemoattractant protein-1; NAP2 , neutrophil activating peptide-2; $\mathrm{OA}$, osteoarthritis. 
erichia coli 0111; B4) was obtained from Sigma Chemical Co. (St. Louis, MO). Recombinant ENA-78 was provided by one of the authors (A. Walz). Phytohemagglutinin (PHA) was obtained from BurroughsWellcome (Research Triangle Park, NC). Neutralizing rabbit anti-human ENA-78 antibody and the antibody used to detect ENA-78 in our ELISA were produced as previously described (3). Rabbit anti-human IL-8 antibody was produced as described previously (see reference 9). mAb Leu-M5 (anti-CD11c, p150,95, CR4 receptor) was used to detect macrophages (Becton Dickinson and Co., Mountain View, CA). mAb FVIII was used to detect Factor VIII-related antigen present on endothelial cells (Dako Corp., Carpinteria, CA).

Patient population. Synovial fluids were isolated from patients with either RA, OA, or other forms of arthritis during therapeutic arthrocentesis. Peripheral blood specimens (serum or plasma) were obtained from some of the RA patients as well as from healthy volunteers. Synovial fluids and peripheral blood were used for isolation of mononuclear cells. Synovial tissue was obtained from patients undergoing total joint replacement who met the American College of Rheumatology criteria for RA or OA $(5,6)$. Normal synovial tissues were obtained from fresh autopsies. Synovial tissues from these patients were snap frozen in OCT (Miles Laboratories Inc., Elkhart, IN). Alternatively, fresh RA synovial tissues were used for isolation of macrophages or fibroblasts (see below). All specimens were obtained with the approval of the Institutional Review Board.

Isolation of human RA synovial fluid and blood mononuclear cells and PMNs. Mononuclear cells from heparinized RA synovial fluid were isolated by gradient centrifugation using Histopaque-1077 (Sigma Chemical Co.), as previously described (7). Mononuclear cells were isolated from the peripheral blood of RA patients and normal volunteers, using Sepracell-MN (Sepratech Corp., Oklahoma City, OK), as described (8). PMNs were isolated from normal peripheral blood using Ficoll-Hypaque density centrifugation followed by sedimentation in $5 \%$ dextran in normal saline followed by hypotonic lysis of erythrocytes (Accurate Chemical \& Scientific Corp., Westbury, NY) (9). Cells (2 $\times 10^{6}$ cells $/ \mathrm{ml}$ ) were incubated in the presence or absence of PHA ( 1 $\mu \mathrm{g} / \mathrm{ml})$ or LPS $(5 \mu \mathrm{g} / \mathrm{ml})$ and cultured in 24-well plates for $90 \mathrm{~h}$ at $37^{\circ} \mathrm{C}$ in RPMI plus $10 \%$ FCS.

Isolation of human synovial tissue fibroblasts and macrophages and preparation of conditioned media. Fresh synovial tissue was minced and digested in a solution of dispase, collagenase, and DNase, as described previously $(10,11)$. Isolated synovial fibroblast cells were cultured in RPMI plus $10 \%$ FCS plus gentamicin $(50 \mu \mathrm{g} / \mathrm{ml})$ in $75-\mathrm{mm}$ tissue culture flasks (Costar Corp., Cambridge, MA). Upon reaching confluence, the cells were trypsinized and passaged (10). The confluent cells were used at passages $4-7$, at which time there was no evidence for passenger cells. The cells $\left(4 \times 10^{5}\right.$ cells $\left./ \mathrm{ml}\right)$ in serum-free RPMI were plated in each well of 24-well plates in the presence or absence of IL$1 \beta(40 \mathrm{ng} / \mathrm{ml})$, TNF- $\alpha(100 \mathrm{ng} / \mathrm{ml})$, or LPS $(1 \mu \mathrm{g} / \mathrm{ml})$ and conditioned media harvested after $24 \mathrm{~h}$.

For isolation of macrophages, the RA synovial tissue was minced and digested as described above. The resultant single-cell suspensions were fractionated into density-defined subpopulations by isopyknic centrifugation through continuous performed Percoll gradients (Pharmacia LKB Biotechnology, Piscataway, NJ). Macrophages were enriched by adherence to fibronectin-coated collagen gels and selective trypsinization (incubation with trypsin/EDTA for 5-10 min) $(10,11)$. Macrophages were harvested from the collagen gels by treatment with clostridial collagenase and found to be $\geq 90 \%$ pure, as assessed by $F_{c}$ receptormediated phagocytosis of IgG opsonized sheep red blood cells, nonspecific esterase staining, and staining with commercial antimacrophage mAbs $(10,11)$. In some cases, macrophages were cultured in the presence or absence of IL-1 $\beta(30 \mathrm{ng} / \mathrm{ml})$ in serum-free RPMI for $8 \mathrm{~h}$ and mRNA isolated. In other experiments, fresh macrophages were cultured in serum-free RPMI for $24 \mathrm{~h}$ and conditioned medium collected.

ENA-78 ELISA. 96-well plates (Nunc, Kamstrup, Denmark) were coated with $50 \mu \mathrm{l} /$ well rabbit anti-ENA-78 $(3.2 \mu \mathrm{g} / \mathrm{ml}$ in $0.6 \mathrm{M} \mathrm{NaCl}$, $0.26 \mathrm{M} \mathrm{H}_{3} \mathrm{BO}_{4}$, and $0.08 \mathrm{~N} \mathrm{NaOH}, \mathrm{pH} \mathrm{9.6)} \mathrm{for} 16 \mathrm{~h}$ at $4^{\circ} \mathrm{C}$ and then washed in PBS, pH 7.5, 0.05\% Tween-20 (wash buffer). Nonspecific binding sites were blocked with 2\% BSA in PBS $(200 \mu \mathrm{l})$, and the plates were incubated for $90 \mathrm{~min}$ at $37^{\circ} \mathrm{C}$. Plates were rinsed $(\times 3)$ with wash buffer, and diluted (neat, 1:5, and 1:10) specimens $(50 \mu \mathrm{l})$ in duplicate were added, followed by incubation for $1 \mathrm{~h}$ at $37^{\circ} \mathrm{C}$. Plates were washed $(\times 4)$, and $50 \mu 1 /$ well biotinylated rabbit anti-ENA-78 $(6 \mu \mathrm{g} / \mathrm{ml}$ in PBS, pH 7.5, $0.05 \%$ Tween-20, $2 \%$ FCS $)$ was added for $45 \mathrm{~min}$ at $37^{\circ} \mathrm{C}$. Plates were washed $(\times 4)$, streptavidin-peroxidase conjugate was ( $100 \mu \mathrm{g} / \mathrm{ml})$ (Dako Corp.) added, and the plates were incubated for $30 \mathrm{~min}$ at $37^{\circ} \mathrm{C}$. The plates were washed $(\times 3)$, and $100 \mu \mathrm{l}$ chromogen substrate $(0.67 \mathrm{mg} / \mathrm{ml}$ orthophenylenediamine dichloride $)$ (Dako Corp.) was added. The plates were incubated at $25^{\circ} \mathrm{C}$ for $6-10$ min, and the reaction was terminated with $50 \mu \mathrm{l} /$ well of $3 \mathrm{M} \mathrm{H}_{2} \mathrm{SO}_{4}$ solution in wash buffer plus $2 \%$ FCS. Plates were read at $490 \mathrm{~nm}$ in an ELISA reader. Standards were $1 / 2 \log$ dilutions of recombinant ENA78 from $100 \mathrm{ng} / \mathrm{ml}$ to $1 \mathrm{pg} / \mathrm{ml}(50 \mu \mathrm{l} /$ well $)$. The ELISA consistently detected ENA-78 concentrations above $50 \mathrm{pg} / \mathrm{ml}$ and did not detect IL$1 \alpha, I L-1 \beta, I L-1$ receptor antagonist, IL-4, IL-6, IL-7, IL-8, monocyte chemoattractant protein-1 (MCP-1), transforming growth factor- $\beta$ (TGF- $\beta$ ), TNF- $\alpha$, gro $\alpha$, neutrophil activating peptide-2 (NAP-2), or $\gamma \mathrm{IP}-10(3)$.

Northern blot analysis. Total cellular RNA was obtained from 2.5 $\times 10^{6} \mathrm{RA}$ synovial tissue macrophages using our previously described method $(12,13)$. Cells were isolated after culture in the presence or absence of IL-1 $\beta(20 \mathrm{ng} / \mathrm{ml})$ for $8 \mathrm{~h}$. Briefly, cells were scraped into a solution containing $25 \mathrm{mM}$ Tris, $\mathrm{pH} 8.0,4.2 \mathrm{M}$ guanidine isothiocyanate, $0.5 \%$ Sarkosyl (Sigma Chemical Co.), and $0.1 \mathrm{M}$ 2-mercaptoethanol. After homogenization, the suspension was added to a solution containing an equal volume of $100 \mathrm{mM}$ Tris, $\mathrm{pH} 8.0,10 \mathrm{mM}$ EDTA, and $1 \%$ SDS. The mixture was then extracted with chloroform-phenol $(1: 1 ; \mathrm{vol} / \mathrm{vol})$ and chloroform-isoamyl alcohol $(1: 1 ; \mathrm{vol} / \mathrm{vol})$. The RNA was alcohol precipitated, and the pellet was dissolved in diethylpyrocarbonate-treated $\mathrm{H}_{2} \mathrm{O}$. Total RNA was electrophoretically separated by denaturing using formaldehyde, $1 \%$ agarose gels, followed by transblotting onto nitrocellulose, baking, prehybridizing, and hybridizing with a ${ }^{32} \mathrm{P}-5$ ' end-labeled oligonucleotide probe. A 30-mer oligonucleotide probe was synthesized using the published cDNA sequence for humanderived ENA-78 (2). The probe was complementary to nucleotides 4777 and had the sequence 5'-CAC-CTT-GGA-GCA-CTG-TGG-GCCTAT-GGC-GAA- $3^{\prime}$. Equivalent amounts of total RNA per gel were assessed by monitoring $28 \mathrm{~s}$ and $18 \mathrm{~s}$ rRNA.

Bioassay for chemotactic activity for PMNs. Normal human PMNs were obtained from peripheral blood by Ficoll-Hypaque density gradient centrifugation. PMNs were suspended in Hank's Balanced Salt Solution (HBSS) with calcium and magnesium (Gibco Laboratories, Grand Island, NY) at $2 \times 10^{6}$ cells $/ \mathrm{ml}$ with $>95 \%$ viability by trypan blue exclusion. Chemotaxis was performed as described previously (9). In brief, $150 \mu \mathrm{l}$ of synovial fluid which was diluted 1:1 with $\mathrm{HBSS}, 10^{-7}$ M FMLP (Sigma Chemical Co.), or HBSS alone was placed in duplicate bottom wells of a blind-well chemotaxis chamber. A 3- $\mu \mathrm{m}$ pore size polyvinylpyrrolidone-free polycarbonate filter (Nucleopore Corp., Pleasanton, CA) was placed in the assembly, and $250 \mu \mathrm{l}$ of PMN suspension was placed in each of the top wells. Chemotaxis chambers were incubated at $37^{\circ} \mathrm{C}$ in humidified $95 \%$ air $/ 5 \% \mathrm{CO}_{2}$ for $1 \mathrm{~h}$. The filters were removed, fixed in absolute methanol, and stained with $2 \%$ toluidine blue (Sigma Chemical Co.). PMNs that had migrated through to the bottom of the filter were counted in 10 high power fields $(\times 200)$ using a chromachip camera (Javelin Electronics, Japan) attached to a Olympus BH-2 microscope interfaced with a Macintosh IIfx computer containing an Image Capture 1000 frame grabber (Scion Corp., Frederick, MD) and Image 1.40 software as described (N.I.H. Public Software, Bethesda, MD) (14). In neutralization studies, synovial fluid was incubated with a 1:1,000 dilution of control rabbit nonimmune serum, ENA-78 antiserum, or a combination of ENA-78 and IL-8 antisera and for $30 \mathrm{~min}$ at $37^{\circ} \mathrm{C}$ before analysis in the chemotactic assay. These dilutions of antisera were found to be optimal in neutralizing ENA-78 or IL-8 (data not shown).

Immunoperoxidase staining. Frozen synovial tissue sections $(4 \mu \mathrm{m})$ were cut and immunoperoxidase stained using an avidin-biotin technique 


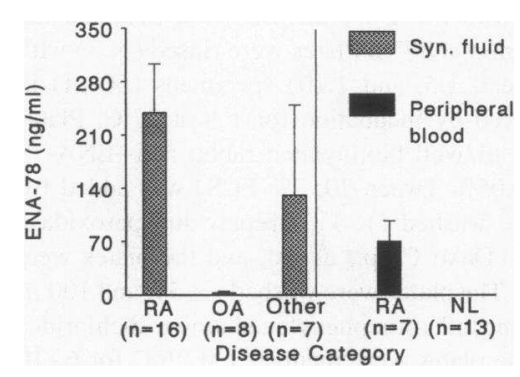

Figure 1. Antigenic ENA-78 levels in synovial fluid from various arthritides as well as RA and normal peripheral blood. Results represent the mean \pm SE. Six replicate determinations per patient were performed. $n$ represents the number of patients examined.

(Vector Laboratories, Burlingame, CA) (15-17). Slides, air dried for 2-16 h, were fixed in cold acetone for $20 \mathrm{~min}$. All subsequent incubations were performed for $15 \mathrm{~min}$ at $37^{\circ} \mathrm{C}$ in a moist chamber. Synovial tissues were pretreated with $50 \mu \mathrm{l}$ diluted normal horse serum $(135 \mu \mathrm{l}$ horse serum in $10 \mathrm{ml} 1 \%$ PBS-BSA), incubated with either rabbit antihuman ENA-78, preimmune rabbit serum, mAb Leu-M5, or control $\mathrm{mAb}$, and washed $(\times 2)$. The slides were incubated with a 1:400 dilution of anti-rabbit biotinylated antibody in PBS-BSA, washed $(\times 2)$ with PBS, incubated with avidin-conjugated horseradish peroxidase complex, and washed with PBS $(\times 2)$. Slides were then stained with diaminobenzidine tetrahydrochloride substrate for $5 \mathrm{~min}$ at room temperature, rinsed in tap water for $2 \mathrm{~min}$, counterstained with Harris' hematoxylin, and dipped in saturated lithium carbonate solution for bluing. Serial tissue sections were examined to determine the percentage of each cell type expressing antigenic ENA-78.

Cytospin preparations of isolated RA synovial tissue macrophages were made using $10^{5}$ cells/slide in a Shandon I cytospin (Shandon Inc., Sewickley, PA). Slides were stained using immunohistochemistry as described above.

Statistical analysis. Statistical analysis was performed using an analysis of variance (18). Correlations were performed using a Pearson correlation. $P$ values $<0.05$ were considered significant.

\section{Results}

Antigenic ENA-78 is elevated in synovial fluid from $R A$ as compared with synovial fluid from $O A$ or other arthritis. ENA78 was measured by ELISA using samples obtained from 31 patients (Fig. 1). RA synovial fluids demonstrated significantly elevated levels of ENA-78 $(239 \pm 63 \mathrm{ng} / \mathrm{ml})(\mathrm{SE})$. In contrast, OA synovial fluid ENA-78 levels were found to be almost 100fold less $(2.6 \pm 1.8 \mathrm{ng} / \mathrm{ml})(P<0.05)$. In addition, synovial fluid from patients with other forms of arthritis including chronic myelogenous leukemia (1), mixed connective tissue disease (1), polymyositis (1), acute rheumatic fever (1), and Reiter's syndrome (2) had significantly higher ENA-78 levels $(130 \pm 118 \mathrm{ng} / \mathrm{ml})$ than patients with OA $(P<0.05)$. Of the patients with other connective tissue diseases, the lowest value $(2.4 \mathrm{ng} / \mathrm{ml})$ was found in synovial fluid from the patient with acute rheumatic fever, while the highest value $(841 \mathrm{ng} / \mathrm{ml})$ was found in synovial fluid from the patient with mixed connective tissue disease. ENA-78 was measured in RA peripheral blood $(70 \pm 26 \mathrm{ng} / \mathrm{ml})$ and was found to be significantly higher than found in normal peripheral blood $(0.12 \pm 0.04 \mathrm{ng} / \mathrm{ml})$ $(P<0.05)$.

$R A$ synovial fluid ENA-78 is chemotactic for normal peripheral blood PMNs. To examine whether RA synovial fluid ENA78 was biologically active, we determined the relative contribution of RA synovial fluid ENA-78 for the chemotaxis of normal peripheral blood PMNs. PMNs were incubated with either pre-

Table I. Chemotaxis of Normal Human Peripheral Blood PMNs in Response to RA Synovial Fluids Incubated in the Presence and Absence of Anti-ENA-78*

\begin{tabular}{lccc}
\hline & \multicolumn{3}{c}{ Mean cells/high power field $(\times 200)$} \\
\cline { 2 - 4 } Patient & Nonimmune serum & Anti-ENA-78 & Percent suppression $^{\ddagger}$ \\
\hline 1 & 321 & 152 & 53 \\
2 & 300 & 168 & 44 \\
3 & 320 & 141 & 56 \\
4 & 481 & 212 & 56 \\
5 & 160 & 158 & 1 \\
& & & Mean $42 \pm 9$
\end{tabular}

(SE)

* RA synovial fluids were diluted 1:1 in HBSS and assayed for their ability to induce chemotaxis of normal peripheral blood PMNs. The results represent the analysis of 10 high power fields per sample. The ability of anti-ENA-78 to neutralize chemotactic activity of PMNs was determined. Positive control migration in response to FMLP $\left(10^{-7} \mathrm{M}\right)$ was a mean of 580 cells/high power field. Negative control migration in response to HBSS was a mean of $12 \pm 4$ cells/high power field. ${ }^{\ddagger} P$ for percent suppression in all patient samples assayed with the exception of patient 5 was $<0.05$.

immune or anti-ENA-78 antibodies (Table I). Preincubation with either antibody did not alter the response to FMLP-induced chemotaxis. In contrast, preincubation with anti-ENA-78 resulted in a $42 \pm 9 \%$ (SE) suppression of PMN chemotactic activity in synovial fluids obtained from five RA patients.

To determine the relative contribution of ENA-78 compared with IL-8 in synovial fluid PMN chemotactic activity, either cytokine or both cytokines were neutralized using anti-IL-8 and anti-ENA-78. Using three RA synovial fluids, ENA-78 accounted for $38-62 \%$ (mean $49 \%$ ) of the PMN chemotactic activity in these fluids, while IL-8 accounted for comparable amounts (44-59\%, mean 49\%). Preincubation of synovial fluids with anti-ENA-78 and anti-IL-8 resulted in a slightly increased suppression of PMN chemotaxis (44-70\%, mean $58 \%$ ), with two of three synovial fluids showing significantly increased suppression of PMN chemotaxis compared with suppression attributable to anti-IL-8 alone $(P<0.05)$.

$R A$ mononuclear cells produce ENA-78: augmentation with LPS or PHA stimulation. We next determined the synovial fluid

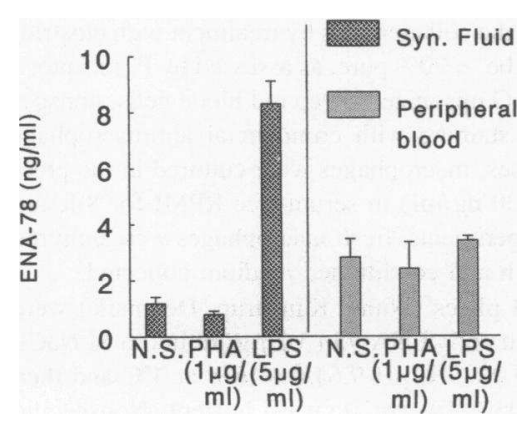

Figure 2. Mononuclear cells were isolated from matching synovial fluid and peripheral blood obtained from three RA patients. Cells $\left(2 \times 10^{6}\right.$ cells/ml RPMI plus $10 \%$ FCS) were cultured for $90 \mathrm{~h}$ in the presence or absence of LPS or PHA, and supernatants were collected. Supernatants were assayed for antigenic ENA-78 by ELISA assay. Results represent the mean $\pm \mathrm{SE}$ of six replicate determinations. 


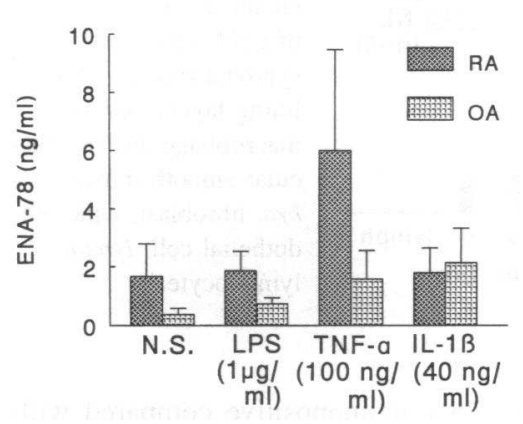

cell types which might be responsible for the production of ENA-78. RA mononuclear cells were obtained from matched synovial fluid and peripheral blood from three RA patients. Cells $\left(2 \times 10^{6}\right.$ cells $/ \mathrm{ml}$ RPMI plus $10 \%$ FCS $)$ were cultured with or without LPS or PHA for $90 \mathrm{~h}$, and their supernatants were assayed for antigenic ENA-78 (Fig. 2). Peripheral blood mononuclear cells as well as synovial fluid mononuclear cells released ENA-78. Synovial fluid ENA-78 levels were augmented upon incubation of synovial fluid mononuclear cells with LPS but not PHA. Parallel experiments were conducted using normal peripheral blood mononuclear cells. ENA-78 release from these cells was not statistically different from that obtained using RA peripheral blood mononuclear cells (data not shown).

Synovial tissue fibroblast production of ENA-78. We next determined whether cells isolated from RA synovial tissue produced ENA-78. Fibroblasts were isolated from three RA patients and four OA patients and cultured in the presence or absence of IL- $1 \beta$, TNF- $\alpha$, or LPS, and supernatants were collected after $24 \mathrm{~h}$. While incubation of RA synovial tissue fibroblasts with LPS or IL- $1 \beta$ resulted in little augmentation of ENA-
78 secretion, incubation with TNF- $\alpha(100 \mathrm{ng} / \mathrm{ml})$ resulted in augmentation of ENA-78 production from $1.3 \pm 0.8$ to $3.1 \pm 1.5$ $\mathrm{ng} / \mathrm{ml}$ (Fig. 3). OA fibroblasts augmented their production of ENA-78 upon incubation with TNF- $\alpha$ and IL-1 (from $0.14 \pm 0.08$ to $0.55 \pm 0.31$ or $0.77 \pm 0.38 \mathrm{ng} / \mathrm{ml}$, respectively). Interestingly, RA fibroblast-conditioned medium contained almost 10 times higher baseline levels of ENA-78 compared with conditioned medium from OA fibroblasts $(1.3 \pm 0.85$ vs $0.14 \pm 0.08 \mathrm{ng} / \mathrm{ml}$, respectively), indicating greater spontaneous production of this cytokine in RA as compared with OA fibroblasts.

RA synovial tissue macrophage production of ENA-78. RA synovial tissue macrophages $\left(1 \times 10^{6}\right.$ cells $\left./ \mathrm{ml}\right)$ obtained from four patients were cultured in serum-free RPMI for $24 \mathrm{~h}$ without agonists, conditioned medium harvested, and assayed for ENA78. Macrophages produced a mean of $16.1 \pm 8 \mathrm{ng} / \mathrm{ml}$ ENA-78. Additionally, RA synovial tissue macrophages expressed steady state ENA-78 mRNA (Fig. $4 A$ ). We have shown that IL- $1 \beta$ is a stimulus for the expression of ENA-78 by normal peripheral blood monocytes (4). We wished to determine whether IL- $1 \beta$ increased ENA-78 expression by RA synovial tissue macrophages. When incubated with IL- $1 \beta(30 \mathrm{ng} / \mathrm{ml})$, these cells produced greater levels of steady state ENA-78 mRNA. By immunohistochemistry, freshly isolated RA synovial tissue macrophages expressed antigenic ENA-78 (Fig. $4 \mathrm{C}$ ). Normal synovial tissues did not yield sufficient isolated macrophages for analysis of ENA-78 expression. However, to determine expression of antigenic ENA-78 by these cells in situ, immunohistology was performed on frozen normal synovial tissues (see below).

ENA-78 expression in synovial tissues. To ascertain which cells in synovial tissues were responsible for ENA-78 production in vivo, we performed immunohistochemistry on frozen synovial tissue samples from 9 patients with RA, 10 patients with $\mathrm{OA}$, and on 3 normal synovial tissues (Figs. 5 and 6). Immunopositive cells were found to be mainly lining cells and subsynovial macrophages. In RA synovial tissues, $39 \pm 9 \%$ (SE)

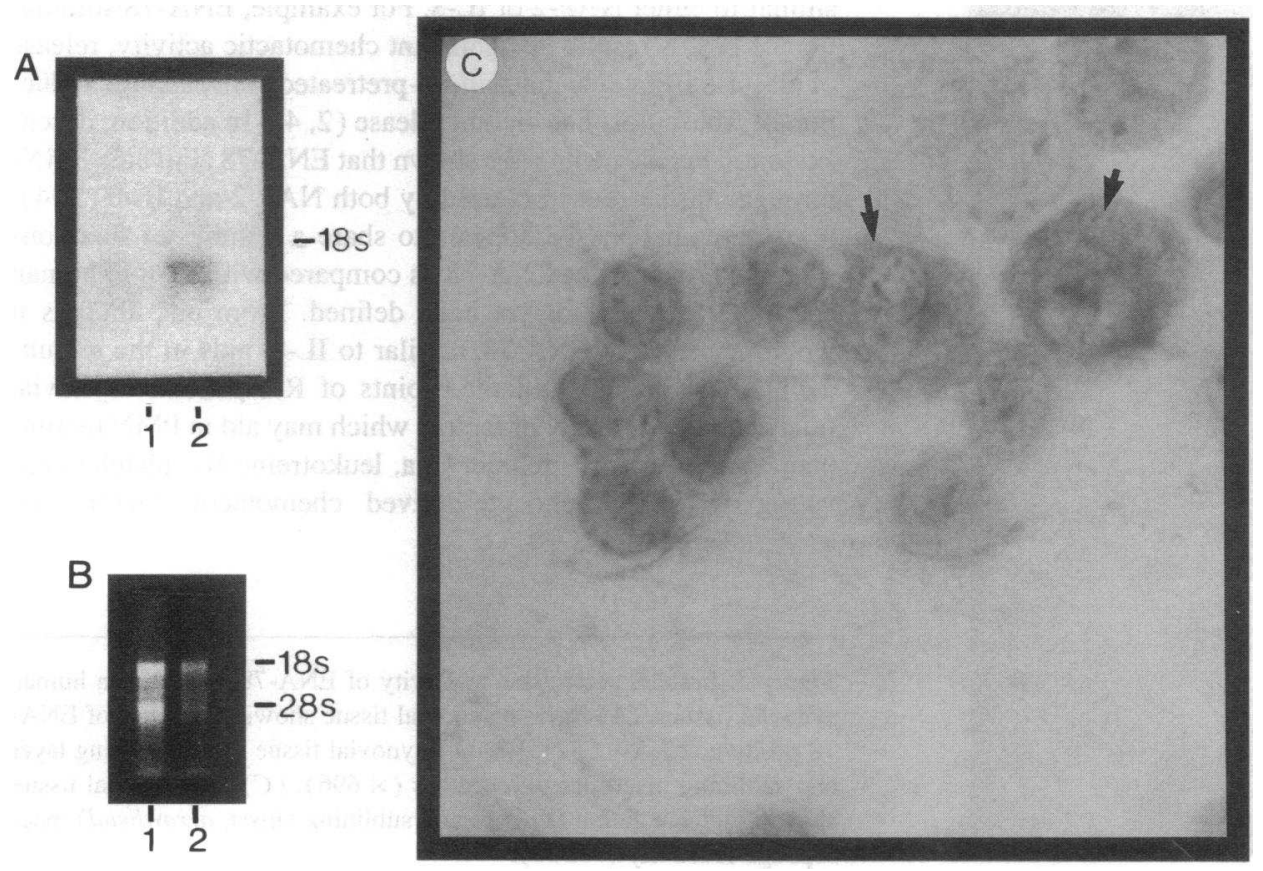

Figure 4. (A) A representative Northern blot showing ENA-78 gene expression from isolated RA synovial tissue macrophages from a representative RA patient without stimulation (lane 1 ) and after stimulation with $\mathrm{IL}-1 \beta(30 \mathrm{ng} / \mathrm{ml})$ for $8 \mathrm{~h}$ (lane 2). (B) $18 \mathrm{~S}$ and $28 \mathrm{~S}$ rRNA demonstrating equivalent loading of total RNA in $A$. (C) Immunoperoxidasestained cytocentrifuge preparation of freshly isolated RA synovial tissue macrophages showing ENA-78 antigen expression (arrows). 


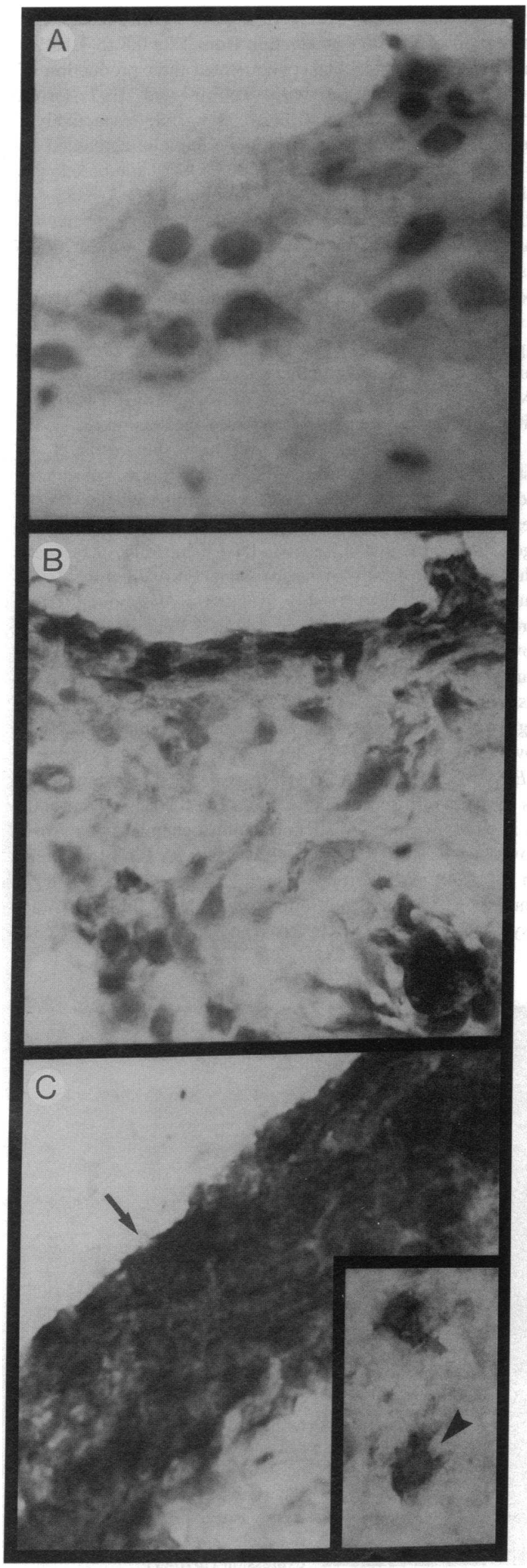

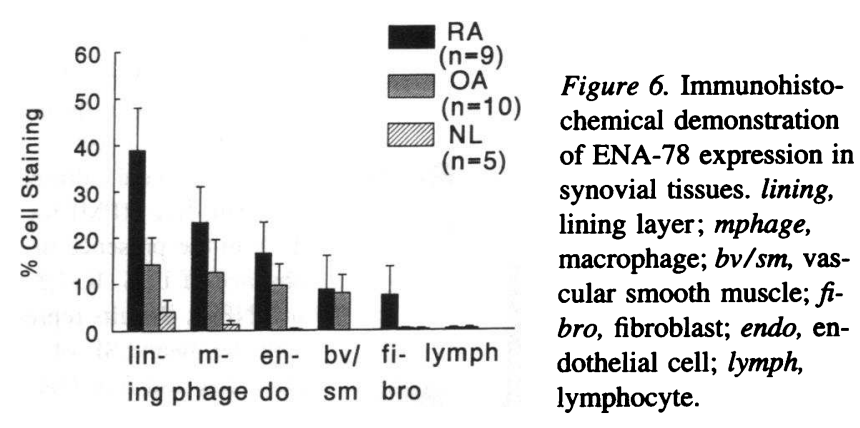

of lining cells were ENA-78 immunopositive compared with $14.2 \pm 5.8 \%$ in $\mathrm{OA}$ and $14.0 \pm 5.8 \%$ in normal synovial tissues. In addition, endothelial cells, vascular smooth muscle cells, and fibroblasts were ENA-78 immunoreactive. Greater numbers of RA macrophages and fibroblasts were ENA-78 immunoreactive in RA as compared with normal synovial tissues $(23.3 \pm 7.7 \%$ macrophages in RA versus $0.66 \pm 0.5 \%$ in normal synovial tissues; $7.44 \pm 6.2 \%$ fibroblasts in RA versus $0 \%$ in normal synovial tissue) $(P<0.05)$ (Figs. 5 and 6$)$.

\section{Discussion}

We have recently identified ENA-78, a potent PMN chemotaxin, in the conditioned medium of human pulmonary epithelial cells (A549) stimulated with TNF- $\alpha(20 \mathrm{ng} / \mathrm{ml})$ or IL-1 $\beta$ (10 $\mathrm{ng} / \mathrm{ml}$ ) (2). ENA-78 is an $8.3-\mathrm{kD}$ protein with 78 amino acids containing 4 cysteines positioned identically to those of IL-8 and its homologues (2). ENA-78 belongs to a supergene family that includes platelet factor-4, platelet basic protein, and its cleavage products (connective tissue activating peptide-III, $\beta$ thromboglobulin, and interferon- $\gamma$-inducible protein, macrophage inflammatory protein- $2 \alpha$, and macrophage inflammatory protein-2 $\beta$ ) (2). ENA-78 shares its closest structural homology to NAP-2 and gro $\alpha$ (53 and $52 \%$ sequence identity) (2).

The functions of ENA-78 are just beginning to be elucidated. ENA-78 shares several properties of PMN activation similar to either NAP-2 or IL-8. For example, ENA-78 stimulation of PMNs results in significant chemotactic activity, release of elastase from cytochalasin-B-pretreated cells, and the induction of free, cytosolic calcium release $(2,4)$. In addition, desensitization experiments have shown that ENA-78 activates PMNs through similar receptors used by both NAP-2 and IL-8 $(2,4)$.

Although ENA-78 appears to share a number of functions with IL-8, the role of ENA-78 as compared with IL-8 in human disease states has not yet been defined. From our findings it would appear that ENA-78, similar to IL-8, aids in the recruitment of PMNs into inflamed joints of RA patients. Synovial fluids contain a variety of factors which may aid in PMN recruitment. These factors include: $\mathrm{C} 5 \mathrm{a}$, leukotreine $\mathrm{B}_{\mathbf{4}}$, platelet-activating factor, lymphocyte-derived chemotactic factor, and

Figure 5. Immunoperoxidase reactivity of ENA-78 with frozen human synovial tissues. $(A)$ Normal synovial tissue showing absence of ENA78 positive cells $(\times 557)$. $(B)$ OA synovial tissue showing lining layer and sublining macrophage reactivity $(\times 696)$. (C) RA synovial tissue showing intense lining (arrow) and sublining (inset, arrowhead) macrophage reactivity $(\times 696)$. 
thrombin $(5,19,20-27)$. In this study, we found significantly greater levels of ENA-78 in synovial fluids from patients with RA as compared with OA or other inflammatory and noninflammatory forms of arthritis. Mean ENA-78 levels in RA synovial fluid were 15 times higher than mean IL-8 levels and 9 times higher than mean MCP-1 levels. Thus, ENA-78 represents one of the most abundant chemokines present in RA synovial fluid. Moreover, ENA-78 found in RA synovial fluids was biologically active. ENA-78 and IL-8 each appear to account for almost half of the RA synovial fluid PMN chemotactic activity in vitro. Preincubation of RA synovial fluids with both antiENA-78 and anti-IL-8 resulted in a mean of 58\% suppression of PMN chemotactic activity. PMNs possess both type A receptors, which are specific for $\mathrm{IL}-8$, and type $\mathrm{B}$ receptors which are promiscuous for all C-X-C chemokines (28). It may be that both receptors are operative, however the type $B$ receptor may be more important since neutralization of either IL-8 or ENA78 alone appears to attenuate the PMN chemotaxis to a similar magnitude. Interestingly, cathepsin G-treated ENA-78 can result in amino-terminal variants of ENA-78 with elevated biological neutrophil-stimulating activity in vitro (our unpublished data). Hence, in the environment of the RA joint which contains numerous proteases, ENA-78 and its amino-terminal variants may induce even greater chemotactic/activating activity on PMNs. In addition, RA is a systemic inflammatory disease, and we found evidence that peripheral blood levels of ENA-78 were higher from RA than normal subjects.

In this study we have characterized the cell types in synovial fluid and synovial tissue responsible for ENA-78 production. Synovial fluid mononuclear cells contributed to ENA-78 production. The production of ENA-78 from these cells was augmented upon incubation with LPS, but not PHA. RA synovial tissue fibroblasts produced ENA-78 particularly upon incubation with TNF- $\alpha(100 \mathrm{ng} / \mathrm{ml})$. TNF- $\alpha$ is also a potent stimulus for the generation of both IL-8 and MCP-1 from these cells (9, 13), emphasizing the concept that the presence of one early response cytokine (TNF- $\alpha$ ) may result in the release of numerous distal cytokines (ENA-78, $\mathbb{L}-8$, and MCP-1) which in turn amplify the immune response $(9,13)$.

We determined the cellular source of ENA-78 in synovial tissue by immunohistochemistry. While a low percentage of normal synovial tissue lining cells express ENA-78 (14\% positive cells), a greater percentage of RA lining cells were ENA78 immunopositive (39\% positive cells). Expression of other chemokines like MIP- $1 \alpha$ was also upregulated in RA compared with normal synovial tissue lining, emphasizing that, while normal tissues do express some cytokines, during inflammation the number of cells expressing these cytokines is markedly increased (27).

Four lines of evidence indicate that the synovial tissue macrophage is a source of ENA-78. First, these cells in culture produce antigenic ENA-78. Second, isolated RA synovial tissue macrophages are ENA-78 immunopositive by immunohistochemistry. Third, isolated RA synovial tissue macrophages produce ENA-78 mRNA, levels of which are increased upon exposure to IL-1 $\beta$. To determine the in situ localization of ENA-78 protein within the cells of synovial tissue, immunohistology was performed. Fourth, synovial tissue ENA-78-positive cells were localized to the lining layer (14\% immunopositive), to macrophages (39\% immunopositive), and, to a lesser extent, endothelial cells and fibroblasts. Furthermore, when comparing RA with normal synovial tissues, greater numbers of RA macro- phages and fibroblasts were expressing ENA-78 protein. Of interest, within the RA synovial tissue, we have shown previously that the main $\mathrm{IL}-8$ and MCP-1 immunopositive cells are also lining cells (24\% positive for $\mathrm{IL}-8$ and $76 \%$ positive for MCP-1) and macrophages (59\% positive for IL-8 and 50\% positive for MCP-1) $(9,13)$. It appears that the RA synovial tissue macrophage is activated to express both members of the C-X-C and C-C chemokine families: ENA-78, IL-8, and MCP-1.

In summary, we have shown that RA compared with OA synovial fluids contain significantly greater quantities of a novel chemotaxin, ENA-78. One of the functions of this chemokine in the RA joint appears to be the recruitment of PMNs. Preincubation of RA synovial fluids suppressed the PMN chemotactic response induced by these synovial fluids by a mean of $42 \%$. Interestingly, multiple cells within the synovial microenvironment are capable of producing ENA-78, with the macrophage being one of the predominant cellular sources of ENA-78 in the RA synovial tissue. In addition, more RA macrophages and fibroblasts expressed ENA-78 in RA compared with normal synovial tissue. These studies imply a biological role for ENA78 in the recruitment of PMNs that characterize the inflamed joints of RA patients.

\section{Acknowledgments}

We thank our colleagues, Drs. S.D. Stulberg, C. Schwartz, J. Galante, N. Rana, B. Briggs, G. Rayan, and J. Lessard for supplying the synovial tissues. We would also like to thank Dr. Herbert Rubinstein and Dr. Frank Schmid for helpful discussions. We wish to acknowledge the invaluable help of Dr. James Sinacore in performing statistical analysis of the data. We are grateful to Ms. Rosa Lovis for isolation of synovial fluid cells and Ms. Manisha Shah for expert photography. We thank Ms. Corinne Washington for expert secretarial assistance.

This work was supported by National Institutes of Health grants AR-30692 and AR-41492 (A. E. Koch), HL-02401 and HL-50057 (R. M. Strieter), HL-31693 (S. L. Kunkel), SCOR grant IP50HL46487 (R. M. Strieter and S. L. Kunkel); The Dr. Ralph and Marion Falk Challenge Prize of the Illinois Chapter Arthritis Foundation (A. E. Koch); and funds from the Veteran's Administration Research Service (A. E. Koch and R. M. Pope). R. M. Strieter is an RJR-Nabisco Research Scholar.

\section{References}

1. Harris, E. D. 1988. Pathogenesis of rheumatoid arthritis: a disorder associated with dysfunctional immunoregulation. In Inflammation: Basic Principles and Clinical Correlates. J. I. Gallin, I. M. Goldstein, and R. Snyderman, editors. Raven Press, New York. 751-773.

2. Walz, A., R. Burgener, B. Car, M. Baggiolini, S. L. Kunkel, and R. M. Strieter. 1991. Structure and neutrophil-activating properties of a novel inflammatory peptide (ENA-78) with homology to interleukin 8. J. Exp. Med. 174:13551362.

3. Strieter, R. M., S. L. Kunkel, M. D. Burdick, P. M. Lincoln, and A. Walz. 1992. The detection of a novel neutrophil-activating peptide (ENA-78) using a sensitive ELISA. Immunol. Invest. 21:589-596.

4. Walz, A., R. M. Strieter, and S. Schnyder. Neutrophil-activating peptide ENA-78. In Chemotactic Cytokines. Plenum Publishing Corp. In press.

5. Arnett, F. C., S. M. Edworthy, D. A. Bloch, D. J. McShane, J. F. Fries, N. S. Cooper, L. A. Healey, S. R. Kaplan, M. H. Liang, H. S. Luthra, et al. 1988. The American Rheumatism Association 1987 revised criteria for the classification of rheumatoid arthritis. Arthritis Rheum. 31:315-324.

6. Altman, R., E. Asch, D. Bloch, G. Bole, D. Borenstein, K. Brandt, W. Christy, T. D. Cooke, R. Greenwald, and M. Hochberg. 1986. Development of criteria for the classification and reporting of osteoarthritis: classification of osteoarthritis of the knee. Arthritis Rheum. 29:1039-1049.

7. Pope, R. M., A. Landay, R. L. Modlin, J. Lessard, and A. E. Koch. 1991. 
$\gamma / \delta \mathrm{T}$ cell receptor positive $\mathrm{T}$ cells in the inflammatory joint: lack of association with response to soluble antigens. Cell. Immunol. 137:127-138.

8. Koch, A. E., P. J. Polverini, S. L. Kunkel, L. A. Harlow, L. A. DiPietro, V. M. Elner, S. G. Elner, and R. M. Strieter. 1992. Interleukin-8 as a macrophagederived mediator of angiogenesis. Science (Wash. DC). 25:1798-1801.

9. Koch, A. E., S. L. Kunkel, J. C. Burrows, H. L. Evanoff, G. K. Haines, R. M. Pope, and R. M. Strieter. 1991. Synovial tissue macrophage as a source of the chemotactic cytokine IL-8. J. Immunol. 147:2187-2195.

10. Koch, A. E., P. J. Polverini, and S. J. Leibovich 1986. Stimulation of neovascularization by human rheumatoid synovial tissue macrophages. Arthritis Rheum. 29:471-479.

11. Koch, A. E., S. J. Leibovich, and P. J. Polverini. 1988. Functional heterogeneity of human rheumatoid synovial tissue macrophages. J. Rheumatol. 15:1058 1063.

12. Koch, A. E., S. L. Kunkel, S. W. Chensue, G. K. Haines, and R. M Strieter. 1992. Constitutive expression of interleukin-1 and interleukin-1 receptor antagonist by human synovial tissue macrophages. Clin. Immunol. Immunopathol. 65:23-29.

13. Koch, A. E., S. L. Kunkel, L. A. Harlow, B. Johnson, H. L. Evanoff, G. K. Haines, M. D. Burdick, R. M. Pope, and R. M. Strieter. 1992. Enhanced production of monocyte chemoattractant protein-1 in rheumatoid arthritis. J. Clin. Invest. 90:772-779.

14. Rolfe, M. W., S. L. Kunkel, T. J. Standiford, M. B. Orringer, S. H. Phan, H. L. Evanoff, M. D. Burdick, and R. L. Strieter. 1992. Expression and regulation of human pulmonary fibroblast-derived monocyte chemotactic peptide-1. Am. J. Physiol. (Lung Cell Mol. Physiol.). 263:L536-545.

15. Koch, A. E., J. C. Burrows, G. K. Haines, T. M. Carlos, J. Harlan, and S. J. Leibovich. 1991. Immunolocalization of leukocyte and endothelial adhesion molecules in human rheumatoid and osteoarthritic synovial tissues. Lab. Invest. 64:313-320.

16. Johnson, B. A., G. K. Haines, L. A. Harlow, and A. E. Koch. 1993. Adhesion molecule expression in human synovial tissue. Arthritis Rheum. 36:137146.

17. Koch, A. E., S. L. Kunkel, W. H. Pearce, M. R. Shah, D. Parikh, H. L. Evanoff, G. K. Haines, M. D. Burdick, and R. M. Strieter. 1993. Enhanced production of the chemotactic cytokines interleukin- 8 and monocyte chemoattrac- ant protein-1 in human abdominal aortic aneurysms. Am. $J$. Pathol 142:1423 1431 .

18. Winer, B. J. 1971. Statistical Principles in Experimental Design. McGrawHill Inc., New York.

19. Firestein, G. S., J. M. Alvaro-Garcia, and R. Maki. 1990. Quantitative analysis of cytokine gene expression in rheumatoid arthritis. J. Immunol. 144:3347-3353.

20. Harris, E. D. 1993. Etiology and pathogenesis of rheumatoid arthritis Textbook of Rheumatology. W. N. Kelley, E. D. Harris, S. Ruddy, and C. B. Sledge, editors. W. B. Saunders Company, Philadelphia. 833-873.

21. Watson, M. L., J. Westwick, N. J. Fincham, and R. D. R. Camp. 1988 Elevation of PMN cytosolic free calcium and locomotion stimulated by novel peptides from IL-1 treated human synovial cell cultures. Biochem. Biophys. Res. Commun. 155:1154-1160.

22. Snyderman, R., and B. C. Lane. 1989. Inflammation and chemotaxis. In Endocrinology, Edition 2. L. J. DeGroot, editor. Grune \& Stratton, Inc., Orlando, FL. 3:2466-2479.

23. Fernandez, H. N., P. M. Henson, A. Otani, and T. E. Hugli. 1978. Chemotactic response to human $\mathrm{C} 3 \mathrm{a}$ and $\mathrm{C5a}$ anaphylatoxins. I. Evaluation of C3a and C5a leukotaxis in vitro and under stimulated in vivo conditions. J. Immunol. 120:109-115.

24. Lee, T. C., and F. Snyder. 1985. Function, metabolism and regulation of platelet activating factor and related ether lipids. In Phospholipids and Cellular Regulation. J. F. Kuo, editor. CRC Press, Inc., Boca Raton, FL. 2:1-39.

25. Ford-Hutchinson, A. W., M. A. Bray, M. V. Doig, M. E. Shipley, and M. J. Smith. 1980. Leukotriene $B_{4}$, a potent chemokinetic and aggregating substance released from polymorphonuclear leukocytes. Nature (Lond.). 286:264265.

26. Korchak, H. M., K. Vienne, L. E. Rutherford, and G. Weissmann. 1984 Neutrophil stimulation: receptor, membrane, and metabolic events. Fed. Proc. 43:2749-2754.

27. Koch, A. E., S. L. Kunkel, L. A. Harlow, D. D. Mazarakis, G. K. Haines, M. D. Burdick, R. M. Pope, and R. M. Strieter. 1994. Macrophage inflammatory protein-1 $\alpha$. A novel chemotactic cytokine for macrophages in rheumatoid arthritis. J. Clin. Invest. 93:921-928.

28. Lee, J., R. Horuk, G. C. Rice, G. L. Bennett, T. Camerato, and W. I Wood. 1992. Characterization of two high affinity human interleukin-8 receptors J. Biol. Chem. 267:16283-16287. 